ROCZNIKI TEOLOGICZNE

Tom LXVIII, zeszyt $10-2021$

DOI: https://doi.org/10.18290/rt.216810.8

ŁUKASZ KWIATKOWSKI

\title{
SKLEPY SOCJALNE JAKO NOWA FORMA WSPARCIA RODZIN ZAGROŻONYCH WYKLUCZENIEM Z POWODU UBÓSTWA
}

\author{
SOCIAL STORES AS A NEW FORM OF SUPPORT FOR FAMILIES THREATENED \\ WITH EXCLUSION DUE TO POVERTY
}

\begin{abstract}
A b s t r a c t. Poverty of families is one of the most serious social problems faced by the modern world, therefore various ways of counteracting it are being sought, one of which is the establishment of social stores. The topic of social stores is still little known in Poland, as evidenced by the establishment of only one such facility so far. The Austrian and German experiences show, however, that this is an effective solution in the fight against poverty-related exclusion and that it is worth using on a larger scale. The article attempts to analyze the functioning of social stores in terms of counteracting the social problem of family poverty. The article moves from theoretical considerations on poverty and the exclusion of families for this reason to the description of social stores as an effective tool for counteracting poverty. The literature on family poverty was reviewed and the basics of social work in the field of counteracting exclusion in Poland and the European Union were described. The summary of the article contains recommendations that may constitute the basis for setting the directions of social work in the area of family support.
\end{abstract}

Keywords: social stores; family; poverty; social exclusion.

\section{WPROWADZENIE}

Ubóstwo rodzin jest jednym z najpoważniejszych problemów społecznych, z jakimi ma do czynienia współczesny świat. Istnieje wiele możliwości inter-

Mgr ŁUKaSz KwiATKOWSKI - Katedra Pedagogiki Społecznej, Instytut Pedagogiki, Uniwersytet Marii Curie-Skłodowskiej w Lublinie; adres do korespondencji: ul. Narutowicza 12, 20-004 Lublin; e-mail: lukasz.kwiatkowski@ poczta.umcs.lublin.pl; ORCID: https://orcid.org/ 0000-0002-9582-9430. 
pretowania pojęcia ubóstwa. Zgodnie z definicją Komisji Europejskiej „ubóstwo odnosi się do osób, rodzin, grup osób, których zasoby (materialne, kulturowe i społeczne) są ograniczone w takim stopniu, że wyklucza to je z normalnego sposobu życia w kraju, w którym mieszkają" ${ }^{1}$. Celem niniejszego artykułu jest dokonanie analizy materiałów dotyczących sklepów socjalnych jako narzędzia przeciwdziałania ubóstwu rodzin. Artykuł przechodzi od rozważań teoretycznych na temat ubóstwa i wykluczenia rodzin z tego powodu do opisu sklepów socjalnych. Dokonano przeglądu literatury dotyczącej zjawiska ubóstwa rodzin, opisane będa podstawy pracy socjalnej w zakresie przeciwdziałania wykluczeniu w Polsce i Unii Europejskiej.

Zjawisko ubóstwa jest pojęciem złożonym i wymaga przyjęcia wielowymiarowego podejścia. Można powiedzieć, że ubóstwo oznacza posiadanie niedostatecznej ilości pożywienia, ubrań, leków potrzebnych jednostce lub rodzinie. Ubóstwo może oznaczać również brak dostępności do edukacji, do korzystania $\mathrm{z}$ opieki zdrowotnej. Problem dotyka również sfery pozyskania środków finansowych na zaspokojenie podstawowych potrzeb, które pozwolą na funkcjonowanie w kraju zamieszkania ${ }^{2}$. W literaturze opisane sa przyczyny ubóstwa, które można przyporządkować do trzech grup: osobowe, subiektywne i obiektywno-strukturalne ${ }^{3}$.

Wykluczenie społeczne, obok ubóstwa, z którym jest intensywnie powiązane, jest problemem społecznym oraz politycznym, który ostatnimi czasy, biorąc pod uwagę również okoliczności pandemii, przybiera mocno na sile. Zdefiniowanie wykluczenia społecznego jest niełatwym zadaniem, ponieważ istnieje wiele wymiarów, które należy przeanalizować. Wykluczenie opisuje sytuację, która w znacznym stopniu utrudnia lub ogranicza jednostkom lub grupom pełnienie ról społecznych, korzystanie z dóbr publicznych oraz infrastruktury społecznej, zbieranie niezbędnych zasobów oraz pracowanie i zarabianie w godny sposób ${ }^{4}$. Określając jednostki lub grupy, objęte wykluczeniem społecznym, można brać pod uwagę: wykluczenie ekonomiczne, wykluczenie edukacyjne oraz kulturowe, wykluczenie z pewnego obszaru terytorium, wykluczenie religijne, wykluczenie polityczne, wykluczenie etniczne,

\footnotetext{
${ }^{1}$ Poverty and inequality in the EU, dostęp 20.04.2021, https://www.eapn.eu/images/docs/po verty\%20explainer_web_en.pdf.

2 Barbara Małgorzata Kałdon, „Rodzina jako instytucja społeczna w ujęciu interdyscyplinarnym", Forum Pedagogiczne 1(2011): 228-241.

${ }^{3}$ Izabela Kumor, „Ubóstwo - ujęcie teoretyczne”, Edukacja Humanistyczna 1(2011): 101-102.

${ }^{4}$ Stanisława Golinowska, Piotr Broda-Wysocki, ,Kategorie ubóstwa i wykluczenia społecznego. Przegląd ujęć”, w Ubóstwo i wykluczenie społeczne, red. Stanisława Golinowska, Elżbieta Tarkowska, Irena Topińska (Warszawa: IPiSS, 2005), 27.
} 
wykluczenie dostępu do informacji i cyfryzacji, wykluczenie osób z zaburzeniami psychicznymi i niepełnosprawnościami ruchowymi. Zjawisko wykluczenia społecznego jest pojęciem, które trudno jest zdefiniować w sposób jednoznaczny, a zarazem wskazać skuteczne formy rozwiązania tego problemu. Świadczy ono o braku zaspokojenia przez jednostkę podstawowych potrzeb życiowych i społecznych oraz braku uczestnictwa jednostki w kluczowych aspektach życia społecznego i zawodowego 5 .

Koncepcja wykluczenia społecznego ma swoje podstawy w rozważaniach dotyczących polityki społecznej ogólnie. Wnosi ona wartość dodaną do sposobu myślenia o polityce społecznej w kontekście rozwoju, może dać pewne ramy do analizy społecznych skutków niekorzystnej sytuacji gospodarczej oraz konsekwencji ekonomicznych. Wykluczenie społeczne wywiera negatywny wpływ na jakość kapitału ludzkiego, ogranicza aktywność społeczną i zawodową oraz przedsiębiorczość, a także zwiększa koszty funkcjonowania państwa. Osobą wykluczoną może być każdy, kto pozbawiony jest szans na aktywne uczestnictwo w ważnych aspektach życia społecznego. Wynika to między innymi z nierówności dochodowych, ale również z nierównego dostępu do edukacji na odpowiednim poziomie, do rzetelnie wynagradzanej pracy oraz zabezpieczenia społecznego. Czynniki te są składowymi określającymi szanse życiowe człowieka i przekładają się na jakość życia ${ }^{6}$.

Pomimo rozwoju gospodarczego i szybkiego postępu technologicznego ok. 12 mln mieszkańców Unii Europejskiej doświadczyło wykluczenia wynikającego z ograniczonych zasobów finansowych. Podstawą badań nad ubóstwem są wskaźniki wykluczenia społecznego. Wynikiem badań jest identyfikacja skali wykluczenia, przyczyn procesu wykluczenia oraz rozpoznanie związanego z nim ryzyka. Ukazanie przyczyn wykluczenia z kolei daje większe możliwości dostosowania adekwatnej formy pomocy osobom najbardziej potrzebującym. Do pomiaru poziomu ubóstwa w Polsce wykorzystuje się wskaźniki opracowane w Strategii Europa $2020^{7}$.

W Strategii Europa 2020, która została opracowana na szczeblu instytucji Unii Europejskiej w celu ograniczenia ubóstwa i wykluczenia społecznego, po raz pierwszy użyto sumarycznego wskaźnika poziomu ubóstwa „ludność zagrożona ubóstwem i wykluczeniem społecznym" (people at risk of poverty

\footnotetext{
${ }^{5}$ Golinowska, Broda-Wysocki, „Kategorie ubóstwa”, 31.

${ }^{6}$ Wioletta Klimczak, Grzegorz Kubiński, Ewa Sikora-Wiśniewska, Wykluczenie społeczne w Polsce. Wybrane zagadnienia (Wrocław: Wydawnictwo EXANTE 2017), 12.

7 „Strategia Europa 2020”, dostęp 20.04.2021, https://www.gov.pl/web/rozwoj-praca-tech nologia/strategia-europa-2020.
} 
or social exclusion). Miernik ten składa się z trzech wskaźników: stopa ryzyka zagrożenia ubóstwem po społecznych transferach (at-risk poverty rate after social transfers - ARPR); wskaźnik deprywacji materialnej (severely materially deprived people) oraz wskaźnik niskiego wykorzystania zasobów pracy (people living in households with very low work intensity) ${ }^{8}$. Gdy dana osoba spełnia więcej niż jedno $\mathrm{z}$ przyjętych kryteriów (dochodowe, deprywacji materialnej, niewykorzystania pracy), w statystykach pojawia się tylko raz, co daje jaśniejszy obraz sytuacji. Według Eurostatu za zagrożonych ubóstwem uważa się osoby, które funkcjonują w gospodarstwach domowych, w których dyspozycyjny dochód ekwiwalentny jest niższy od granicy zagrożenia ubóstwem ustalonej na poziomie $60 \%$ mediany dyspozycyjnego ekwiwalentnego dochodu w danym kraju' ${ }^{9}$ Biorąc pod uwagę inny wskaźnik, jakim jest miernik deprywacji materialnej, Eurostat określa osoby jako „dotknięte poważną deprywacją materialnaą", jeśli nie mogą one pozwolić sobie na zaspokojenie co najmniej czterech z dziewięciu potrzeb materialnych lub bytowych uznanych we współczesnych warunkach europejskich za podstawowe ${ }^{10}$. Trzeci wskaźnik dotyczy niskiego wykorzystania zasobów pracy i obejmuje on osoby w wieku 0-59 lat żyjące w gospodarstwach domowych o bardzo niskiej intensywności wykorzystania pracy, czyli gospodarstwach, w których w minionym roku osoby dorosłe pracowały w wymiarze mniejszym niż $20 \%$ ich całkowitego potencjału pracy ${ }^{11}$. Jak wynika z raportu Polska 2020. Obok nas. Fakty o biedzie, przygotowanego przez Szlachetną Paczkę, 900 tys. dzieci w Polsce doświadczyło ubóstwa, a 300 tysięcy żyje w skrajnym ubóstwie. Niemal 85\% rodzin, które korzystają z pomocy Szlachetnej Paczki, boryka się z chorobami, niepełnosprawnością i brakiem środków finansowych ${ }^{12}$.

W Polsce minimalny próg egzystencji na rok 2019 wynosił około 614 zł dla osoby żyjącej samotnie, dla rodziny z dwójką dzieci było to około 1658 zł. W skali województw w Polsce najwyższy wskaźnik zagrożenia ubóstwem lub

\footnotetext{
${ }^{8}$ Małgorzata Sulmicka, „Cele edukacyjne Strategii Europa 2020 a Polska”, Prace i Materiaty Instytutu Rozwoju Gospodarczego SGH. Polityka gospodarcza jako gra w wyzwania i odpowiedzi rozwojowe 94(2014): 194.

9 „Eurostat”, dostęp 20.04.2021, https://ec.europa.eu/eurostat/web/products-statistical-boo ks/-/KS-EP-09-001.

10 „A statistical portrait of the European Union2010”, dostęp 20.04.2021, https://ec.europa. eu/eurostat/web/products-statistical-books/-/KS-EP-09-001.

11 „Eurostat”.

12 „Polska 2020. Obok nas. Fakty o biedzie”, dostęp 02.07.2021, https://www.szlachetnap aczka.pl/raport-o-biedzie/.
} 
wykluczeniem społecznym występuje w woj.: lubelskim, lubuskim, zachodniopomorskim, świętokrzyskim oraz podkarpackim ${ }^{13}$.

Przegląd literatury pokazuje, że przyczyn i źródeł ubóstwa rodzin można poszukiwać w czynnikach ekonomicznych, jak i pozaekonomicznych ${ }^{14}$. Badacze zjawiska klasyfikują przyczyny ubóstwa w trzy grupy: osobowe, subiektywne oraz obiektywno-strukturalne ${ }^{15}$. Przyczyny z grupy osobowej są niezależne od jednostki i zalicza się do nich: niepełnosprawność fizyczną, niepełnosprawność umysłową, choroby przewlekłe, czy podeszły wiek. Osoby, które znajdują się w tej grupie, nie są w stanie samodzielnie funkcjonować, ponieważ nie mogą zapewnić sobie minimalnego poziomu egzystencji, a ze względu na swoją niesamodzielność są też zagrożone wykluczeniem z życia społecznego. Druga grupa czynników, to przyczyny subiektywne, do których zaliczane są te zależne od jednostki, np. postawy i cechy charakteru. W ich skład wchodzi wyuczona bezradność, destrukcyjny system wartości, brak przestrzegania zasad społecznych, postawa niechęci do pracy i nauki, brak umiejętności gospodarowania zasobami ${ }^{16}$. Grupa trzecia to przyczyny obiektywno-strukturalne, które są niezależne od woli jednostki czy grupy. Zalicza sie do niej świadczenia udzielane przez państwo, co może przekładać się na zmniejszenie motywacji do pracy czy nauki ${ }^{17}$.

\section{PRZECIWDZIAŁANIE WYKLUCZENIU SPOŁECZNEMU W POLSCE I UNII EUROPEJSKIEJ}

Proces zwalczania ubóstwa oraz wykluczenia społecznego rodzin jest szeroko wpisany w cele poszczególnych krajów Unii Europejskiej, a także

\footnotetext{
13 „Zasięg ubóstwa w Polsce”, dostęp 20.04.2021, https://stat.gov.pl/download/gfx/porta linformacyjny/pl/defaultaktualnosci/5487/14/7/1/zasieg_ubostwa_ekonomicznego_w_polsce_w 2019_r.pdf.

${ }^{14}$ Izabela Kaźmierczak-Kałużna, ,Ubóstwo jako problem społeczny: kwestie terminologiczne i ustalenia empiryczne", Kultura i Społeczeństwo 1(2015): 147-157.

15 Kumor, „Ubóstwo - ujęcie teoretyczne, 101.

${ }^{16}$ Iwona Niewiadomska, Mirosław Kalinowski, Skazani na wykluczenie (Lublin: Wydawnictwo KUL, 2010), 37; Alicja Antas-Jaszczuk, Agnieszka Roguska, Ubóstwo jako kwestia spoteczna w percepcji studentów pedagogiki (Siedlce: Uniwersytet Przyrodniczo-Humanistyczny 2020), 65; Ewelina Mazgaj, „Ubóstwo jako problem społeczny XXI wieku oraz sposoby jego zwalczania", w: Wyzwania i problemy spoteczne poczatku XXI wieku, red. Norbert Laurisz (Kraków: Fundacja GAP, 2020), 87.

${ }^{17}$ Mazgaj, „Ubóstwo”, 88; Antas-Jaszczuk, Roguska, Ubóstwo jako kwestia społeczna, 45; Mazgaj, „Ubóstwo”, 90.
} 
Wspólnoty jako całości. Walka z ubóstwem jest procesem długotrwałym i wieloaspektowym, który obecnie znajduje się we wszystkich programach związanych z rozwojem społecznym. Realizacja tego celu odbywa się poprzez działania na szczeblu lokalnym, regionalnym, krajowym i europejskim w zakresie polityki społecznej, polityki zatrudnienia czy ochrony socjalnej. W Polsce działania, mające na celu przeciwdziałanie wykluczeniu materialnemu, sa zawarte w wielu krajowych programach i strategiach, takich jak: Krajowy Program Przeciwdziałania Ubóstwu i Wykluczeniu Społecznemu 2020 czy Strategia Rozwoju Kraju 2020, a także aktualne opracowania - Długookresowa Strategia Rozwoju Kraju. Polska 2030; Trzecia fala nowoczesności czy Strategia Sprawne i Nowoczesne Państwo 2030. Podstawowym założeniem tych programów jest tworzenie dla jednostek i rodzin szans oraz zasobów, które pozwolą im na uczestniczenie w życiu społecznym i zawodowym. Również Unia Europejska podejmuje działania, które mają na celu walkę z ubóstwem i wykluczeniem rodzin. Na przestrzeni lat zostało stworzonych wiele programów, których priorytetem jest poprawa warunków bytowych osób ubogich i wykluczonych. Aktualnie najważniejszym dokumentem europejskim jest strategia „Projekt Europa 2030. Wyzwania i Szanse”18. Zawarte sa w niej wytyczne służące do podejmowania działań na rzecz proaktywnego wspierania społeczności i jednostek zagrożonych wykluczeniem oraz wykluczonych z powodu ubóstwa.

W Polsce walka z ubóstwem rodzin również jest priorytetowym zadaniem, co wynika z przyjętych strategicznych projektów polityki społecznej. Ich celem jest tworzenie dla ludzi zagrożonych ubóstwem i wykluczeniem szans, a także zasobów, które mają być wykorzystane do uczestniczenia w swobodnym funkcjonowaniu ekonomicznym, społecznym i kulturalnym. W opracowanych strategiach podstawą do działań są wytyczne odnoszące się do wsparcia rodzin i osób przez świadczenia społeczne (np. programy rządowe, zasiłki czy świadczenia celowe), czy też działania prowadzące do wyrównywania szans rozwojowych oraz przeciwdziałanie zaniedbaniom wynikającym z deprywacji różnych potrzeb w gospodarstwach domowych. $Z$ ubóstwem zmaga się również znaczna część osób z niepełnosprawnościami ruchowymi czy umysłowymi, dlatego $\mathrm{w}$ przyjętych strategiach zostały zawarte takie działania, jak: przygotowanie infrastruktury dla niepełnosprawnych, umożliwienie komunikacji z otoczeniem oraz szansa na uczestnictwo w swobodnym funkcjonowaniu społecznym. Ważną rolę $\mathrm{w}$ zapisach strategii odgrywa również grupa

\footnotetext{
18 „Projekt Europa 2030”, dostęp 20.04.2021, https://espas.secure.europarl.europa.eu/orbis/d ocument/project-europe-2030-challenges-and-opportunities.
} 
seniorów, którym z kolei pomaga się poprzez zwiększenie dostępności świadczeń zdrowotnych, a także aktywizację na rynku pracy.

Głównym zadaniem państwa opiekuńczego jest poprawa sytuacji osób lub grup znajdujących się w niekorzystnej sytuacji poprzez dostarczanie świadczeń i wsparcie. Działając jednak na rzecz zwiększenia aktywności osób zagrożonych wykluczeniem i wykluczonych z powodu ubóstwa, poza działaniami instytucjonalnymi, warto korzystać również z doświadczeń sektora pozarządowego. W tym obszarze szeroko rozwinięte działania podejmowane są przez państwa zachodnie, między innymi wykorzysujące aspekt społecznej odpowiedzialności biznesu, czy aktywizację społeczną.

\section{SKLEPY SOCJALNE \\ JAKO PRZYKŁAD DZIAŁANIA INKLUZYJNEGO}

Dobrym przykładem działań wspierających osoby ubogie i zagrożone ubóstwem są kraje języka niemieckiego, gdzie bardzo popularnym rozwiązaniem są sklepy socjalne. W Austrii pierwszy sklep socjalny został otwarty w 1999 roku w Linz jako sposób na zapewnienie zdrowej i niedrogiej żywności osobom, których nie stać na te produkty. W ciagu ostatnich dwudziestu lat liczba sklepów społecznych w Austrii wzrosła do 37. Ideą działania tych sklepów jest wykorzystanie nadwyżek żywności nadającej się do spożycia i innych produktów, takich jak środki czyszczące i pielęgnacyjne, które eliminowane są ze zwykłego łańcucha dostaw z różnych powodów, takich jak uszkodzenie opakowania, nadprodukcja lub nieprawidłowe etykietowanie. Sklepy socjalne w Austrii zbierają nadwyżki towarów od przedsiębiorstw przemysłowych i handlowych, a następnie sprzedają te produkty za symboliczną cenę osobom o udokumentowanych niskich dochodach. Ma to na celu stworzenie wartości dodanej dla przemysłu, handlu i osób dotkniętych ubóstwem ${ }^{19}$.

W celu określenia wartości dodanej, jaką generują sklepy socjalne, przeprowadzono badanie, w którym określono wartość SROI, czyli stopy społecznego zwrotu inwestycji ${ }^{20}$. Analiza objęła 28 sklepów socjalnych w Austrii oraz związanych z nimi kawiarni. Korzyści dla interesariuszy oceniono w ka-

\footnotetext{
${ }^{19}$ Sandra Stötzer, Rene Andeßner, Sarah Scheichl, ,Charity flea markets - an amalgamation of product philanthropy and volunteering”, International Review on Public and Nonprofit Marketing 17(2020): 10; Christian Grünhaus, Constanze Beeck, Mayram Shabal, Social Return on Investment Analysis of the Food Banks of SOMA Österreich \& Partner (Wienna: pubWU, 2019), 9.

${ }^{20}$ Grünhaus, Beeck, Mayram Shabal, Social Return, 9.
} 
tegoriach pieniężnych. Na podstawie przeprowadzonych badań okazuje się, że efekty pieniężne za 2018 rok wyniosły 95559232 euro. Największa społeczna wartość dodana pojawia się dla klientów sklepów. Ich udział w całkowitym wpływie wynosi $76,9 \%$. Są to efekty pieniężne o wartości 73482844 euro. W 2018 roku około 28900 klientów regularnie robiło zakupy w sklepach społecznościowych, w szczególności zyskując na oszczędnościach finansowych i podwyższonej jakości życia oraz jakości funkcjonowania psychologicznego, które wynikają z większego zakresu finansowego, mniejszej liczby zmartwień finansowych i bardziej pozytywnych doświadczeń zakupowych ${ }^{21}$. Sklepy socjalne umożliwiają klientom zakup szerokiej gamy produktów, wypróbowanie nowych produktów, na które zwykle ich nie stać.

Drugi co do wielkości wynik wartości dodanej jest generowany przez wycenioną pracę wolontariuszy, która miała wartość pieniężną w wysokości 6331013 euro (6,6\%). W 2018 roku na 28 analizowanych rynkach społecznościowych do pracy wolontariackiej zgłosiły się 494 osoby. Takie doświadczenie daje korzyści z wykonywania sensownej pracy, która kształtuje codzienne życie i daje pozytywne poczucie robienia czegoś dobrego. Zwiększa się także świadomość dotycząca grup defaworyzowanych i problemu marnotrawienia żywności.

Trzecia co do wielkości społeczna wartość dodana powstaje dla środowiska w wyniku ograniczenia marnotrawienia żywności, co przekłada się na 5,8\% udziału w wartości rynku. Ograniczając wyrzucanie żywności, można ją konsumować, ale również ogólnie produkować mniej żywności. W ujęciu pieniężnym wskaźnik ten wynosi 5086668 euro $^{22}$.

Całkowita społeczna wartość dodana przedsięwzięcia, jakim są sklepy socjalne w Austrii, daje wartość SROI na poziomie 8,47. Oznacza to, że każde euro zainwestowane $\mathrm{w}$ funkcjonowanie sklepów społecznościowych SOMA Austria \& Partner generuje efekty w postaci ekwiwalentu pieniężnego w wysokości 8,47 euro. Jest to relatywnie wysoka wartość SROI, co wynika z faktu, że sklepy socjalne przy stosunkowo niewielkich inwestycjach generują pozytywne korzyści dla bardzo dużej grupy klientów. Podsumowując, rynki społecznościowe SOMA Austria \& Partner są bardzo efektywne. Monetyzowane efekty społeczne, obejmujące 2018 r., były ponad ośmiokrotnie wyższe niż dokonane inwestycje finansowe ${ }^{23}$.

\footnotetext{
21 Tamże, 10.

22 Tamże, 45.

23 Tamże, 19
} 
Idea walki z ubóstwem poprzez wykorzystanie narzędzi i inicjatyw związanych z angażowaniem społecznym podejmowana jest na różne sposoby również w innych krajach. Najczęściej zakładane są sklepy charytatywne lub realizowane są inicjatywy ekonomii współdzielenia. Najlepiej rozwiniętym rodzajem sklepów charytatywnych na świecie są sklepy z artykułami spożywczymi oraz z odzieżą, które działaja już od lat osiemdziesiątych XX wieku w wielu krajach na świecie, np. w Niemczech, Włoszech, Finlandii czy Wielkiej Brytanii ${ }^{24}$. Z kolei idea ekonomii współdzielenia jest trendem, który rozwija się od kilkunastu lat na całym świecie i dotyczy koncepcji społeczno-gospodarczej zbudowanej w oparciu o ideę wspólnego dostępu do zasobów, których używają ludzie ${ }^{25}$. Stanowi ona model rozwojowy, w którym konsumpcję postrzega się jako możliwość współużytkowania różnych dóbr z innymi ludźmi ${ }^{26}$.

Sklepy socjalne dostarczają towary, które stanowią obciążenie dla firm i jednocześnie przynoszą wymierną korzyść osobom zagrożonym wykluczeniem oraz wykluczonym społecznie z powodu ubóstwa. Chociaż zakres korzyści płynących ze sklepów socjalnych dla klientów jest szeroki, wszyscy korzystają z tego potencjału. Podczas gdy jedne grupy mają korzyść materialną, bo moga pozwolić sobie na więcej w innych obszarach dzięki oszczędnościom, inni klienci czują ulgę psychiczną od trosk egzystencjalnych ${ }^{27}$.

\section{SKLEPY SOCJALNE - ANALIZA SYTUACJI W POLSCE}

Przywołane w poprzednim paragrafie sklepy socjalne, czyli Sozialmärkte są wśród rozwiązań zachodnich jednym z bardziej popularnych i innowacyjnych narzędzi. W Polsce nie jest ono jeszcze popularne, dlatego warto przyjrzeć się temu rozwiązaniu bliżej. Jeśli chodzi o naukowy dyskurs na temat sklepów socjalnych, to zarówno w polskiej, jak i anglojęzycznej literaturze trudno znaleźć informacje na ten temat. Rozwiązania te opisane są szerzej w literaturze niemieckiej.

\footnotetext{
${ }^{24}$ Lambie-Mumford Hannah, Silvasti Tina, The Rise of Food Charity in Europe (Bristol: Policy Press, 2020).

${ }^{25}$ Łukasz Zgiep, ,Sharing economy jako ekonomia przyszłości”, Myśl Ekonomiczna i Polityczna 47(2014): 193.

${ }^{26}$ Alex Stephany, The bussiness of sharing. Making it in the new sharing economy (New York: Palgrave Macmillan, 2015).

${ }^{27}$ Stötzer, Andeßner, Scheichl, „Charity flea markets-an amalgamation of product philanthropy and volunteering", 13.
} 
$\mathrm{Na}$ podstawie analizy różnorodnych źródeł internetowych, m.in. takich jak strony www dla Polonii mieszkającej w krajach niemieckich, czy też portale informacyjne, można wysnuć wnioski, że sklepy socjalne to forma wsparcia dla osób i całych rodzin w trudnej sytuacji materialnej, które mogą zakupić głównie żywność i artykuły pierwszej potrzeby w cenach znacznie niższych niż rynkowe - zwykle w wysokości $1 / 3$ ceny rynkowej. Towar nabywany jest najczęściej bezpośrednio u producentów. Są to na przykład produkty w uszkodzonych opakowaniach bądź z krótkim okresem przydatności do spożycia. Dokumentem upoważniającym do zakupów jest legitymacja. Wystawiana jest ona na podstawie zaświadczenia o wysokości zarobków, meldunku, dowodu osobistego oraz po sprawdzeniu sytuacji klienta. Z racji tego, że sklepy przeznaczone są dla osób z niskimi dochodami, miesięczne zarobki klientów powinny mieścić się, w zależności od sklepu, w kwocie nieprzekraczającej 800-900 euro. Poza tą kwotą większość sklepów akceptuje również posiadanie dodatku na dziecko, pod warunkiem, że nie przekracza on określonej sumy. Maksymalna tygodniowa wartość zakupów nie może przekroczyć 30-35 euro. Ten warunek ma przeciwdziałać robieniu zakupów hurtowych i na przykład droższemu odsprzedawaniu produktów osobom trzecim.

Rosnące powodzenie sklepów Sozialmärkte pokazuje, że osób w trudnej sytuacji wciąż przybywa. Sklepy dla najbardziej potrzebujących funkcjonują z powodzeniem w całej Austrii. SOMA Sozialmarkt to stowarzyszenie, które wiele lat temu zapoczątkowało w Austrii ideę sprzedaży artykułów spożywczych i pierwszej potrzeby po cenach znacznie niższych niż rynkowe ${ }^{28}$.

Na bazie doświadczeń austriackich, również w Polsce powstał pierwszy sklep socjalny „Spichlerz”, otwarty w grudniu 2020 roku przez Fundację Wolne Miejsce. Główną ideą sklepu socjalnego jest pomoc osobom, które znalazły się w trudnej sytuacji materialnej poprzez umożliwienie im zrobienia zakupów w cenach do 50\% ich wartości rynkowej. Drugi powód, dla którego powstał sklep, to chęć przeciwdziałania marnotrawieniu żywności i produktów spożywczych ${ }^{29}$.

Z oferty sklepu mogą skorzystać zarówno objęci już pomocą Miejskiego Ośrodka Pomocy Społecznej, jak również osoby i rodziny, które do tej pory z takiej pomocy nie korzystały. Decyduje kryterium dochodowe - do 1402 zł w przypadku osoby samotnej lub 1056 zł w przeliczeniu na każdą osobę w rodzinie. Zakupy w Spichlerzu można zrobić na dwa sposoby. Pierwszym jest zaświadczenie z MOPS-u, który wydaje swoim podopiecznym karty do-

\footnotetext{
${ }^{28}$ „Forum polonijne”, dostęp 20.04.2021, http://www.polonika.at/index.php/poradnik/porady -prawne/1262-dokad-po-pomoc.

29 „Spichlerz”, dostęp 20.04.2020, https://wolnemiejsce.pl/spichlerz.
} 
stępu (na razie w wersji papierowej, ale niedługo zostaną zamienione na elektroniczne). Korzystać ze sklepu moga także wszyscy seniorzy, którzy ukończyli 75 lat. Jeśli z uwagi na pandemię lub stan zdrowia nie chcą wychodzić z domu, mogą zadzwonić na tzw. srebrny telefon, który uruchomiony został w Katowicach, wolontariusz dowiezie zakupy do mieszkania. Wszystkie inne osoby w potrzebie, które np. straciły pracę, mogą przyjść do kawiarenki, która działa przy Spichlerzu w Katowicach i w określony dzień skonsultować się z wolontariuszami pracującymi na rzecz wspierania tych osób. Pracownik fundacji przeprowadza wywiad na temat sytuacji danej osoby i przyznaje jej czasowy dostęp do sklepu, np. na miesiąc. Docelowo kawiarenki mają być miejscem spotkań, będą tam pracować psychologowie i terapeuci.

W Spichlerzu można wydać maksymalnie 100 zł dziennie i kupić tylko jeden produkt $\mathrm{z}$ danej kategorii towarów. Limity nie obowiązują jednak na towary takie, jak pieczywo, nabiał, wędliny czy warzywa. Fundacja planuje otworzenie sklepów socjalnych we wszystkich większych miastach, następnie w miejscowościach i na wsiach. Ostatnim etapem będą sklepy mobilne, w formie autobusów, które mają pełnić rolę sklepów z tanim towarem, ale też będą to miejsca integracji ${ }^{30}$.

\section{PODSUMOWANIE}

Zjawisko ubóstwa i wykluczenia społecznego rodzin to problem powszechny i dostrzega się go w krajach o zróżnicowanym poziomie rozwoju. Pomimo wysokiego poziomu życia mieszkańców Europy, nadal borykamy się z problemem biedy i możliwości adekwatnego, a przede wszystkim efektywnego wspierania osób. W Unii Europejskiej istnieje wciąż dysproporcja między państwami, które efektywnie radzą sobie w walce z ubóstwem, a tymi, które odnotowują duży odsetek osób ubogich i potrzebujących. Sytuacja w Polsce określana jest jako lepsza niż średnia unijna, przewaga Polski nie jest jednak znaczna, a ubóstwem dotkniętych jest blisko $7 \mathrm{mln}$ osób. Z tej przyczyny warto pochylić się nad analizą realizowanych działań i czerpać z doświadczeń krajów, które wprowadziły efektywne rozwiązania $\mathrm{w}$ tym zakresie.

Nie istnieje jeden uniwersalny sposób walki z ubóstwem i wykluczeniem rodzin. Problem ubóstwa jest cały czas aktualny, co potwierdza przyznanie Nagrody Nobla z nauk ekonomicznych w 2019 roku badaczom zajmującym się

\footnotetext{
${ }^{30}$ „Sklep socjalny w Polsce”, dostęp 20.04.2020, https://businessinsider.com.pl/twoje-pienia
} dze/budzet-domowy/sklep-socjalny-w-katowicach-kto-i-kiedy-moze-zrobic-w-nim-zakupy/70rx9ff. 
obszarem ubóstwa i łagodzenia jego skutków. Walka z ubóstwem i wykluczeniem jest priorytetem polityki społecznej, a budowanie świadomości ludzi oraz zainspirowanie obywateli Europy do angażowania się w walkę z nim przyniesie pozytywne efekty dla całej populacji. Jest to zdecydowanie zjawisko, które ma destrukcyjny wpływ nie tylko na jednostki czy rodziny, ale również ma ogromne znaczenie dla całych społeczeństw.

Nie ulega wątpliwości, że pełne przeanalizowanie wszystkich zasobów oraz deficytów systemu wsparcia osób ubogich w Polsce powinno stać się głównym celem podejmowanych badań o charakterze ogólnopolskim, w wielu dyscyplinach naukowych, w tym w obszarze polityki społecznej. Analiza mocnych i słabych stron systemu wsparcia osób ubogich aktualnie ma charakter otwarty, podobnie jak lista narzędzi wspierających ich pozytywną readaptację. Korzystając ze sprawdzonych doświadczeń państw zachodnich, można pokusić się o stworzenie rekomendacji, które wytyczałyby kierunki pracy socjalnej w Polsce, z uwzględnieniem efektywnego rozwiązania, jakim są sklepy socjalne. Rekomendacje te będą głównie dotyczyć obszaru systemowego, czyli odnosić się do systemu wsparcia osób wykluczonych i zagrożonych wykluczeniem ze względów ekonomicznych, należałoby wskazać więc na:

- zadbanie (na poziomie systemowym) o odpowiednią aktywizację zawodową osób ubogich, aby mogły one ustabilizować swoją sytuację finansową;

- włączanie osób ubogich do działania na rzecz funkcjonowania sklepu socjalnego, np. działania marketingowe, obsługa sklepu, pomoc w zakupach dla społeczności;

- zawiązanie współpracy systemowej organizacji pozarządowych z sektorem pomocy społecznej w celu usprawnienia procesu zakładania oraz prowadzenia sklepów socjalnych;

- realizację systemowych oraz konkursowych programów i projektów unijnych w zakresie problematyki wykluczenia, w tym kampanii informacyjnych i edukacyjnych dotyczących działania sklepów socjalnych;

- budowanie lokalnych programów walki z problemem ubóstwa i łagodzenia jego skutków, ze szczególnym uwzględnieniem narzędzi o potwierdzonej efektywności, np. sklepów socjalnych;

- wspieranie osób oraz rodzin w walce $\mathrm{z}$ ubóstwem poprzez budowanie odpowiedniej infrastruktury, ze szczególnym uwzględnieniem działania sklepów socjalnych.

Biorąc pod uwagę powyższe refleksje, wydaje się, że wprowadzenie w Polsce rozwiązania, jakim są sklepy socjalne, mogłoby przyczynić się do znacznej poprawy funkcjonowania rodzin borykających się z problemem ubóstwa, a tym samym wykluczenia społecznego. Rozwiązanie to w sposób 
efektywny może również wesprzeć działania instytucjonalne, ponieważ dąży ono do wypracowania u osób postawy proaktywnej, a także niwelowania zjawiska wyuczonej bezradności, które przekłada się na uzależnienie od świadczeń socjalnych.

\section{BIBLIOGRAFIA}

Antas-Jaszczuk, Alicja, Agnieszka Roguska. Ubóstwo jako kwestia społeczna w percepcji studentów pedagogiki. Siedlce: Uniwersytet Przyrodniczo-Humanistyczny, 2020.

„A statistical portrait of the European Union2010”. Dostęp 20.04.2021, https://ec.europa.eu/ eurostat/web/products-statistical-books/-/KS-EP-09-001.

„Eurostat”.Dostęp20.04.2021,https://ec.europa.eu/eurostat/web/products-statistical-books/-/KSEP-09-001.

„Forum polonijne”. Dostęp 20.04.2021, http://www.polonika.at/index.php/poradnik/porady-praw ne/1262-dokad-po-pomoc.

Golinowska, Stanisława, Piotr Broda-Wysocki. „Kategorie ubóstwa i wykluczenia społecznego. Przegląd ujęć”. W Ubóstwo i wykluczenie społeczne, red. Stanisława Golinowska, Elżbieta Tarkowska, Irena Topińska. Warszawa: IPiSS, 2005.

Grünhaus, Christian, Constanze Beeck, Mayram Shabal. Social Return on Investment Analysis of the Food Banks of SOMA Österreich \& Partner. Wienna: pubWU, 2019.

Kałdon, Barbara Małgorzata. „Rodzina jako instytucja społeczna w ujęciu interdyscyplinarnym". Forum Pedagogiczne 1(2011): 228-241.

Kaźmierczak-Kałużna, Izabela. „Ubóstwo jako problem społeczny: kwestie terminologiczne i ustalenia empiryczne”. Kultura i Spoteczeństwo 1(2015): 147-157.

Klimczak, Wioletta, Grzegorz Kubiński, Ewa Sikora-Wiśniewska. Wykluczenie społeczne w Polsce. Wybrane zagadnienia. Wrocław: Wydawnictwo EXANTE, 2017.

Kumor, Izabela. „Ubóstwo - ujęcie teoretyczne”. Edukacja Humanistyczna 1(2011): 101-102.

Lambie-Mumford, Hannah, Silvasti Tiina. The Rise of Food Charity in Europe. Bristol: Policy Press, 2020.

Mazgaj, Ewelina. „Ubóstwo jako problem społeczny XXI wieku oraz sposoby jego zwalczania”. W Wyzwania i problemy społeczne poczatku XXI wieku, red. Norbert Laurisz. Kraków: Fundacja GAP, 2020.

Niewiadomska, Iwona, Mirosław Kalinowski. Skazani na wykluczenie. Lublin: Wydawnictwo KUL, 2010.

„Polska 2020. Obok nas. Fakty o biedzie”. Dostęp 02.07.2021, https://www.szlachetnapaczka. $\mathrm{pl} /$ raport-o-biedzie/.

Poverty and inequality in the EU. Dostęp 20.04.2021. https://www.eapn.eu/images/docs/povert y\%20explainer_web_en.pdf.

„Projekt Europa 2030”. Dostęp 20.04.2021. https://espas.secure.europarl.europa.eu/orbis/docume nt/project-europe-2030-challenges-and-opportunities.

„Sklep socjalny w Polsce”. Dostęp 20.04.2020, https://businessinsider.com.pl/twoje-pieniadze/bu dzet-domowy/sklep-socjalny-w-katowicach-kto-i-kiedy-moze-zrobic-w-nim-zakupy/70rx9ff.

„Spichlerz”. Dostęp 20.04.2020, https://wolnemiejsce.pl/spichlerz.

„Strategia Europa 2020”. Dostęp 20.04.2021, https://www.gov.pl/web/rozwoj-praca-technologia/ strategia-europa-2020. 
Sulmicka, Małgorzata. „Cele edukacyjne Strategii Europa 2020 a Polska”. Prace i Materiaty Instytutu Rozwoju Gospodarczego SGH. Polityka gospodarcza jako gra w wyzwania i odpowiedzi rozwojowe 94(2014): 194.

Stötzer, Sandra, Rene Andeßner, Sarah Scheichl. „Charity flea markets-an amalgamation of product philanthropy and volunteering”. International Review on Public and Nonprofit Marketing 17(2020): 10.

Stephany, Alex. The bussiness of sharing. Making it in the new sharing economy. New York: Palgrave Macmillan, 2015.

„Zasięg ubóstwa w Polsce”. Dostęp 20.04.2021. https://stat.gov.pl/download/gfx/portalinformacy jny/pl/defaultaktualnosci/5487/14/7/1/zasieg_ubostwa_ekonomicznego_w_polsce_w_2019_r.pdf.

Zgiep, Łukasz. „Sharing economy jako ekonomia przyszłości”. Myśl Ekonomiczna i Polityczna 47(2014): 193.

\section{SKLEPY SOCJALNE JAKO NOWA FORMA WSPARCIA RODZIN ZAGROŻONYCH WYKLUCZENIEM Z POWODU UBÓSTWA}

\section{S t r e s z c z e n i e}

Ubóstwo jest jednym z najpoważniejszych problemów społecznych, z jakimi ma do czynienia współczesny świat, $\mathrm{z}$ tego powodu poszukiwane są różne sposoby przeciwdziałania temu zjawisku, jednym z nich jest zakładanie sklepów socjalnych. Temat sklepów socjalnych jest w Polsce nadal mało znany, o czym świadczyć może powstanie do tej pory tylko jednej takiej placówki. Doświadczenia austriackie i niemieckie pokazują jednak, że jest to rozwiązanie efektywne w walce z wykluczeniem z powodu ubóstwa i warte wykorzystania na szerszą skalę. W artykule podjęto próbę analizy funkcjonowania sklepów socjalnych pod kątem przeciwdziałania problemowi społecznemu, jakim jest ubóstwo rodzin. Artykuł przechodzi od rozważań teoretycznych na temat ubóstwa i wykluczenia rodzin z tego powodu do opisu sklepów socjalnych jako efektywnego narzędzia przeciwdziałania ubóstwu. Dokonano przeglądu literatury dotyczacej zjawiska ubóstwa rodzin, opisano podstawy pracy socjalnej w zakresie przeciwdziałania wykluczeniu w Polsce i Unii Europejskiej. Podsumowanie artykułu zawiera rekomendacje, które mogą stanowić podstawę do wyznaczania kierunków pracy socjalnej w obszarze wspierania rodziny.

Słowa kluczowe: sklepy socjalne; rodzina; ubóstwo; wykluczenie społeczne. 